\title{
Bollywood Sinemasını Kamu Diplomasisi Bağlamında Yeniden İzlemek: Bajrangi Bhaijaan Üzerine Bir İnceleme ${ }^{1}$
}

\author{
Zindan Çakıcı \\ Araștırma Görevlis \\ zindan.cakici@uskudar.edu.tr \\ Üsküdar Üniversitesi İletişim Fakültesi \\ ORCID: 0000-0002-8916-0582
}

Emre Meriç

Araștırma Görevlisi emre.meric@fbu.edu.tr Fenerbahçe Üniversitesi Illetişim Fakültesi ORCID: 0000-0001-8006-7149

\begin{abstract}
Re-watching Bollywood Cinema in the Context of Public Diplomacy: An Analysis on "Bajrangi Bhaijaan"

Bollywood cinema is one of India's most important public diplomacy instruments that spreads its own culture, art, and religious aspects. India promotes its own country with Bollywood cinema and exports its cultural goods to other countries through this film industry. In this study, how Bollywood portrays Pakistanis while introducing many of India's soft power elements was researched with the semiotic analysis of Bajrangi Bhaijaan (2015). As a result of the study, it was shown that while Indian culture, art, and religious elements were portrayed with positive images in the film, Pakistanis and Muslims were represented as patriarchal, angry, and conservative.
\end{abstract}

keywords: Public diplomacy, Bollywood, Bajrangi Bhaijaan, representation

118 Aralık 2019 tarihinde gerçekleştirilen Galatasaray Üniversitesi Stratejik Iletişim Yönetimi Konferansları (GSÜStrat) II: "Yeni Kamu Diplomasisi: Diyalog ve İlişki Inş̧a Etme" başıklı ulusal konferansta sözlü bildiri olarak sunulmuştur.

DOI:10.16878/gsuilet.867952 


\section{Résumé}

\section{Repenser le cinéma de Bollywood dans le contexte de la diplomatie publique: une étude sur Bajrangi Bhaijaan}

Le cinéma de Bollywood est l'un des principaux outils de diplomatie publique dans lesquels I'Inde promeut sa propre culture, son art et ses éléments religieux. L'Inde fait la promotion de son propre pays à travers le cinéma Bollywood et commercialise ses produits culturels dans d'autres pays par le biais de cette industrie cinématographique. Cette recherche présente les nombreux éléments de puissance douce de Bollywood sur I'Inde avec l'analyse sémiotique du film Bajrangi Bhaijaan; Il a été analysé comment les Pakistanais sont représentés. À la suite de la recherche, il a été constaté que si la culture, l'art et les éléments religieux de l'Inde étaient présentés avec des images positives dans le film, les Pakistanais et aussi les musulmans étaient représentés comme "patriarcaux", "en colère" et "conservateurs".

mots-clés: Diplomatie publique, Bollywood, Bajrangi Bhaijaan, représentation

\section{Öz}

Bollywood sineması, Hindistan'ın kendi kültürünü, sanatını ve dinsel öğelerini tanıttığı önemli kamu diplomasisi araçlarından biridir. Hindistan, Bollywood sineması üzerinden hem kendi ülkesini tanıtmakta hem de kültürel ürünlerini bu sinema endüstrisi aracılığıyla diğer ülkelere pazarlamaktadır. Bu araştırma, Bajrangi Bhaijaan filminin göstergebilimsel analizi ile Bollywood'un Hindistan'a dair birçok yumuşak güç unsurunu tanıtırken; Pakistanlıları nasıl temsil ettiğini analiz etmiştir. Inceleme sonucunda, filmde Hindistan'ın kültürü, sanatı ve dinsel öğeleri olumlu imgeler ile sunulurken, Pakistanlıların ve bununla birlikte Müslümanların, "ataerkil", "öfkeli" ve "tutucu" olarak temsil edildiği görülmüştür.

anahtar kelimeler: Kamu diplomasisi, Bollywood, Bajrangi Bhaijaan, temsil 


\section{Giriş}

18. yüzyıldan itibaren dış kamuoyu ile ortak paydalar bulma ve köklü ilişkiler inşa etme sürecinin artması, kamu diplomasisinin önemli bir alan olarak ortaya çıkmasını sağlamıştır. Ağ toplumunun görünür olmaya başlaması ile sert güç yerini yumuşak güç unsurlarına bırakmış ve kamu diplomasisi stratejik bir faaliyet alanı olarak gündemde daha fazla yer almaya başlamıştır. Stratejik bir iletişim aracı olarak kamu diplomasisi, dış kamuoyu ile uzun süreli ve köklü ilişkilerin inşa edildiği bir süreci ifade etmektedir. Bu süreçte, diğer ülke halklarının kültürünü, beklentilerini ve bakış açılarını anlamaya çalışmak, kamu diplomasisi pratiklerinin başarıya ulaşması adına önem teşkil etmektedir. Bununla birlikte, kamu diplomasisi süreçlerinde stratejik bir yaklaşıma sahip olmak, ülke menfaatleri açısından oldukça önemlidir. Bu yönüyle de kamu diplomasisi, özellikle dış ilişkilerde pek çok ülke için önemli bir alan haline gelmiştir.

Kamu diplomasisi, propagandanın veya diplomatik reklamcılığın bir uzantısı olarak ortaya çıkmıştır. Fakat, kamu diplomasisi ve propaganda kavramlarının tanımlarına, kullanım amaçlarına, kullandıkları araçlara ve yöntemlere bakıldığında, iki kavram arasında farklılıkların olduğu görülmektedir (Pamment, 2013, s. 2). Kamu diplomasisinde bilgilerin doğru ve güvenilir olması, stratejik iletişim süreçlerinin sağlıklı işlemesi adına oldukça önemlidir. Propaganda da ise verilen bilgilerin doğruluğu ve güvenilirliği önem taşımamaktadır. Kamu diplomasisi bu açıdan propagandadan farklılaşmaktadır (Romarheim, 2005, s. 13). Propaganda, çoğu zaman güvenirlikten yoksundur ve kamu diplomasisi olarak kullanıldığında ters tepmektedir. Bununla birlikte, kamu diplomasisi, amacına uygun bir şekilde kullanılmayıp, kamuoyunu doğru bilgilendirmeyerek "ahlaka" aykırı bir niyet ile kullanıldığında ise propaganda halini almaktadır (Cull, 2007, s. 20). Doğru bilgiye dayanmayan kamu diplomasisi faaliyetleri, sadece inandırıcıığını kaybetmekle kalmayıp ülkelerin mevcut olumlu imajlarına da zarar verebilir. Bu süreçlerde önemli olan, doğru bilgi yayıp uzun süreli ilişkiler kurmaktır. Bu nedenle, kamu diplomasisi faaliyetlerinin, dezenformasyon yayma süreçleri ile karıştırılmaması gerekir (Temel, 2010, s. 36).

Ingiltere'den bağımsızığını 15 Ağustos 1947'de kazanan Hindistan, bağımsızlığını kazanmasından itibaren "kültürel ilişkiler" yoluyla tanınırlığını artıımayı amaçlamaktadır. Günümüzde, yumuşak güç unsurlarını dış kamuoyuna aktarma potansiyeli bulunan Hindistan'ın etkili araçlarından birisi de Bollywood sinemasıdır. Hindistan, Amerika'nın Hollywood filmleri vasıtası ile yaptığı gibi kendi toplumunun düşüncelerini, inançlarını, sosyal, siyasal ve kültürel değerlerini Bollywood üzerinden dış kamuoyuna pazarlamaktadır. Hindistan, Bollywood ile hem geleneklerini, danslarını, giysilerini, müziklerini, mimari üsluplarını ve inançlarını hem de dış politikadaki eylemlerine meşruiyet zemini yaratan fikirleri dış kamuoyuna tanıtmaktadır.

Fakat, Hindistan'ın bağımsızlığını kazanması ile görünür olmaya başlayan 
ve Soğuk Savaş döneminin sona ermesiyle küresel bir boyut kazanan Bollywood sinemasının kamu diplomasisi süreçlerinde Pakistanlılara dair nasıl bir gerçeklik inşa ettiğini inceleyen akademik çalışmaların sayısı oldukça azdır. Göstergebilimsel analizin kullanılı̆̆ı bu araştırmanın amacl; Hindistan'ın, Bollywood sinemasındaki Pakistanlı temsili üzerinden kendini siyasal ve kültürel bağlamda nasıl ön plana çıkarmaya çalıştığını Bajrangi Bhaijaan filmi üzerinden analiz etmektir.

\section{Kamu Diplomasisine Genel Bir Bakış}

20. yüzyılın ikinci yarısından itibaren literatürde daha fazla yer almaya başlayan kamu diplomasisinin izlerine, 19. yüzyılda devletler tarafından gerçekleştirilen geleneksel diplomasi faaliyetlerinde rastlanılmaktadır. Joseph Nye'a göre, Fransa'nın Prusya ile savaşının ardından imajını düzeltmek için 1883 yılında Alliance Française'ı kurarak yurt dışında dil ve kültür faaliyetleri düzenlemesi, kamu diplomasisinin ilk örneklerinden biri olarak kabul edilmektedir (Nye, 2008, s. 101). Bu tarihten itibaren dış kamuoyu, dış politikayı belirleme süreçlerinde etkili bir faktör haline gelmiştir. Devletler, dış politikanın oluşum ve uygulama sürecinde etkin rol oynayan dış kamuoyunu dikkate almaya başlamıştır. Ayrıca, dış kamuoyunun güveninin kazanılması ve zihninde olumlu bir imaj oluşturulması daha önemli hale gelmiştir (Karadağ, 2019, s. 88-114).

Kamu diplomasisi kavramı ilk kez ABD'deki Tufts Üniversitesi Fletcher Hukuk ve Diplomasi Okulu Dekanı Edmung Gullion tarafından 1965 yılında kullanılmıştır. Edmung Gullion, kamu diplomasisi faaliyetlerini "bilgi ve fikirlerin uluslar ötesi akışı" olarak tarif etmiştir. Dış politikaların oluşum ve uygulama süreçlerinde bilgilerin ve fikirlerin ulusötesi akışı, dış kamuoyunun tutum ve algılarını etkileyen bir sürece işaret etmektedir (Sancar, 2012, s. 79). Manheim'e göre, kamu diplomasisi "algıları yönetebilme ve yabancı kamu sektörlerini temel hedefler doğrultusunda yönlendirebilme sanatı"dır (Manheim, 2001, s. 75). Potter ise, kamu diplomasisini "hükümetlerin başka ülkelerin halkını, kanaat önderlerini ve aydınlarını kendi politikaları doğrultusunda olumlu olarak etkileyebilmesi" şeklinde tanımlamıştır (Potter, 2002, s. 2).

Hükümetlerin diğer ülkelerde kamuoyu oluşturması, bu ülkelerin kamu ve özel kuruluşları ile etkileşimde bulunması, diplomatları ve yabancı meslektaşları ile sürdürülebilir iletişim sağlaması temel kamu diplomasisi faaliyetlerindendir. Bu faaliyetler, geleneksel diplomasi çalışmalarından farklı olarak, bilgi ve fikirlerin ulus ötesi akışını sağlayarak dış kamuoyunun tutum ve algılarını etkileyebilir (Sancar, 2012, s. 91). Genel anlamı ile kamu diplomasisi "yabancı kamuoyuna yönelik faaliyetlerde bulunmak ve yabancı kamuoyu ile etkileşim halinde olmak" şeklinde tanımlanmaktadır (Kocabıyık, 2019, s. 166). Anna Tiedeman'a göre kamu diplomasisi, politika geliştirme ve dış ilişkilerin yönlendirilmesi açısından kritik öneme sahip bir iletişim sürecidir. Bu iletişim süreci, hükümetlerin kendi ulusunun ideallerini, düşüncelerini, kültürünü, kurumlarını ve ulusal hedeflerini diğer ülkelerin kamuoyuna anlatmak için gerçekleştirdiği tüm iletişim faaliyetlerini ifade etmektedir (Tiedeman, 2004, s. 6). 
Kamu diplomasisi 1970'lerden itibaren gündemde daha fazla yer almaya başlayan stratejik bir faaliyet alanına dönüşmüştür. 11 Eylül saldırılarından sonra bir tür popülizm kaynağı olarak yükselişe geçen Anti-Amerikancılık, ABD'yi uluslararası kamuoyunda yükselen nefrete karşı çözüm yolları aramaya itmiştir (Karagöz, 2016, s. 49). Kamu diplomasisi faaliyetleri, ABD'de meydana gelen diplomatik sorunlar ile yüzleşmek ve bu sorunlara çeşitli çözüm önerileri geliştirmek adına stratejik bir iletişim yöntemi olarak görülmeye başlanmıştır. Özellikle, Obama döneminde yayınlanan NFSC (The National Framework for Strategic Communication) raporunda, kamu diplomasisi süreçlerinde etkili bir stratejik iletişimin gerekliliği üzerinde durulmuş ve buna yönelik politikaların geliştirilmesinin gerekliliği vurgulanmıştır. Ayrıca, NFSC raporu uluslararası iletişim süreçlerinde sadece elitlerin değil sıradan insanların düşünce ve şikayetlerinin de dinlenmesi gerektiğini belirtmiştir (Taylor, 2009, s. 12).

Kamu diplomasisi süreçlerinde "dış kamuoyunun eğitilmesi, bilgilendirilmesi ve bu süreçlere dâhil edilmesi" gerekmektedir (Efegil, 2018, s. 5). Bu süreçte kamu diplomasisi stratejik bir iletişim aracı olarak değerlendirilmektedir. Stratejik bir iletişim aracı olarak kamu diplomasisi, "kamuoyunu anlamaya çalışmak, bilgilendirmek ve etkilemek" üzerine yapılan faaliyetler bütünü olarak tanımlanmaktadır (Tuch, 1990, s. 3). Kamu diplomasisi süreçlerinde stratejik bir yaklaşıma sahip olmak, ülke menfaatleri açısından da oldukça önemlidir. Bu yönüyle de kamu diplomasisi özellikle dış ilişkilerde pek çok ülke için önemli bir alan haline gelmiştir.

Mark Leonard'a göre, kamu diplomasisinin üç temel unsuru vardır. Bu unsurlardan ilki, iletişimin sürekliliğidir. Leonard, birçok devletin kendi ülkeleriyle ilgili kararları sadece kendi halkına açıkladıklarından dolayı yabancı kamuoyu ile iletişimin süreklilik arz etmediğini dile getirmektedir. Leonard'a göre, kamu diplomasisi süreçlerinin sağlıkı işlemesi için iletişimin sürekliliği esas unsur olmalıdır. Bu süreç zarfında dış kamuoyu, ülkenin politikaları konusunda bilgilendirilmelidir. Leonard'a göre kamu diplomasisinin ikinci unsuru stratejik iletişim süreçleri ile ilişkilidir. Stratejik iletişim süreçlerini doğru bir şekilde yöneten ülkelerin, yabancı kamuoyunun desteğini alabildiğini belirten Leonard, ülkelerin stratejik iletişimlerinin gücü oranında uluslararası alanda bilinirliklerini artırabileceğini ifade etmektedir. Leonard'a göre, kamu diplomasisinin üçüncü unsuru, sivillerin yaptığı günlük iletişim süreçleri ile ilgilidir. Hükümetler, kişiler ya da gruplar temel hedef kitlelerine yönelik gerçekleştirdikleri kamu diplomasisi faaliyetlerinde; burslar, değişim programları, eğitimler, seminerler ve konferanslar gibi çalışmalarla kalıcı ilişkiler inşa edebilir (Leonard, 2002, s. 8-9).

Hans Nathan Tuch'a göre kamu diplomasisi, "hükümetlerin dış kamuoyu ile etkileşimde bulunarak politika değişikliklerine gitmesini, hükümetlerin farkı ülkelerdeki özel kuruluşlar ile hükümet dışı etkileşimde bulunmasını, medyanın uluslararası diplomasi süreçlerindeki rolünü ve tüm bu süreçlerin politika oluşturma ve uygulama üzerindeki etkisini" kapsamaktadır (Tuch, 1990, s. 9). Gifford 
Malone'a göre kamu diplomasisi süreçlerinin çift yönlü yapılandırılması gerekmektedir. Çünkü, bir ülkenin kendi toplumu veya politikaları konusunda dış kamuoyunda istediği gibi bir anlayış geliştirebilmesi için öncelikle "iletişime geçtiği halkın kültürel özelliklerini, psikolojisini ve dilini öğrenmesi gerekmektedir." (Malone, 1988, s. 12). Bu süreç, kamu diplomasisi faaliyetlerinde çift yönlü bir iletişim modelinin kullanımasını zorunlu kılmaktadır.

Joseph Nye, kamu diplomasisini yumuşak gücün bir kullanım alanı olarak görmüş ve kavramı geleneksel diplomasi faaliyetlerinden farklı bir şekilde konumlandırmıştır. Joseph Nye'a göre, devletler her ne kadar yabancı liderler ile yakın ilişkiler kursalar da halk nezdinde olumlu bir izlenim bırakamadıkları sürece diplomatik etkilerinin sınırlı kalacağını ifade etmiş̧tir (Nye, 2005, s. 106). Buradan hareketle, dış kamuoyuna yönelik gerçekleşen kamu diplomasisi çalışmalarının, devletler ve liderler arasında gerçekleşen geleneksel diplomatik süreçlerden daha önemli hale geldiği söylenebilir.

\section{Kamu Diplomasisi ve Yumuşak Güç Kavramı}

Joseph Nye, 1990 yılında yayımlanan Bound to Lead adlı kitapta ilk kez "yumuşak güç" kavramını tanımlamıştır. Bu kavramın etkin olduğu ortamda, uluslararası örgütlerin ve medyanın etkisi artmış; askeri kapasitenin ve klasik orduların yani "sert/kaba güç" unsurlarının etkinliği azalmıştır. Zorbalık yerine iş birliğini ön plana çıkaran Nye, yumuşak gücü; "Eğer istediğim şeyi istemeni sağlayabilirsem, o zaman yapmak istediğim şeyi yapmaya seni zorlamama gerek yoktur." şeklinde ifade etmiştir (Nye, 2003, s. 10-11).

"Yumuşak güç" kavramı, devletlerin hem kendi ulusal çıkarlarını hem de etkilemek istedikleri dış kamuoyunun çıkarlarını göz önünde bulundurarak kurdukları uzun süreli ve köklü ilişkilerin tümü olarak tanımlanabilir (Leonard, 2002, s. 8-9). Yumuşak gücün kullanımında birçok unsur ön plana çıkmaktadır. Bu unsurlar "bir ülkenin askeri veya ekonomik gücünden çok ülkenin kültürü, sanatı, sineması, mimarisi, müziği, eğitim sistemi, özgürlükleri, demokrasisi, sosyal sermayesi, tarihi birikimi, bilim ve teknoloji altyapısı, inovasyon kapasitesi, diplomatik becerisi ve kendini anlatabilme yeteneği"nin toplamıdır. Bu unsurları içinde barındıran ve etkili bir şekilde kullanan bir ülke, cazibe merkezi haline gelir (Sandıklı, 2014, s. 190).

Yumuşak güç; aktöre iliştirilmiş güç ile aktöre doğrudan etkisi olmayan güç kullanımı olarak ikiye ayrılmaktadır. Sahip olunan bilgi ve kültür gibi önemli unsurlar ile bir ülkenin kamuoyuna doğrudan etki edilebileceği gibi; uluslararası örgütler ve kurumlar ile de dış kamuoyuna etki edilebilmektedir. Nye'a göre, günümüz bilgi çağında devlet, medya ile kamuoyunu yönlendirebileceği gibi kamuoyu da medya ile devleti etkileyebilmektedir. Bu süreç çift yönlü bir iletişim ile mümkün olabilmektedir (Nye, 2008, s. 29). 
Devletler, kamu diplomasisi süreçlerinde dış kamuoyuna etki edebilmek adına yumuşak güçten yararlanmaktadır. Jan Melissen, kamu diplomasisini "devletten-halka" ve "halktan-halka" olmak üzere iki ana çerçevede bir araya getirmiştir. Kalın'a göre; "devlet-halk" eksenindeki iletişim faaliyetlerinde; devlet, resmi araçları ve kanalları kullanarak izlediği politikaları ve yaptığı faaliyetleri yabancı kamuya anlatmaktadır (Kalın, 2011, s. 3). Halktan-halka doğrudan iletişim faaliyetlerinde ise STK'lar, araştırma merkezleri, basın ve kanaat önderleri gibi devlet dışı aktörler kullanılmaktadır. Buradan hareketle, kamu diplomasisi "diplomatlar" ve "yabancı kamuoyları" arasında geçen iletişim faaliyetlerinin ötesine geçmiştir (Melissen, 2005, s. 19).

\section{Kamu Diplomasisi ve Propaganda}

Kamu diplomasisi ve propaganda kavramlarının tanımlarına, kullanım amaçlarına, kullandıkları araçlara ve yöntemlere bakıldığında, iki kavram arasında büyük farklılıkların olduğu görülmektedir (Pamment, 2013, s. 2). Welch'e göre propaganda, belirli bir amaç doğrultusunda, doğrudan veya dolaylı şekilde kitlelerin fikirlerini herhangi bir konuda şekillendirme girişimidir (Melissen, 2005, s. 16-17). Propaganda, belli bir amaca ulaşmak adına önceden seçilmiş bilgileri kitlelere kabul ettirmeyi hedeflemektedir. Bu hedefleri takip ederken, etkili ve kalıcı olacağına inanılan semboller geliştirilerek, kitleleri aktif sürece katmayı amaçlamaktadır. Propaganda, bireye seçenek sunmamakla birlikte gerçek dışı tepkiler ve inançlar oluşturarak bireyin duygularına yönelmektedir (Özkan, 2007, s. 167).

Kamu diplomasisi, doğru ve güvenilir bilgilere dayanması açısından propagandadan ayrımaktadır (Romarheim, 2005, s. 13). Kamu diplomasisi, doğru bilgiye yer vermeyerek dış kamuoyunu yanlış yönlendirmesi ile propaganda halini alır (Cull, 2007, s. 20). Doğru bilgiye dayanmayan kamu diplomasisi faaliyetleri sadece inandırıcılığını kaybetmekle kalmayıp ülkelerin mevcut olumlu imajlarına da zarar verebilir. Bu süreçlerde önemli olan, doğru bilgi yayıp kalıcı ilişkiler kurmaktır. Kamu diplomasisi faaliyetlerinin, dezenformasyon yayma süreçleri ile karıştııılmaması gerekir (Temel, 2010, s. 36). Kamu diplomasisi, hitap ettiği halkı kitle olarak ele almamakla birlikte farklı anlayış ve düşüncelere sahip bireyleri anlamaya çalışarak, ortak bir iletişim dili oluşturmaya çalışmaktadır. Bu süreçte kullandığı iletişim iki yönlüdür ve karşııkı belirleyicilik esastır. Ayrıca, kamu diplomasisinin yarattığı etkide de bir karşılıklı belirleyicilik mevcuttur. Güvenilir ilişki ortamının kurulması ile her iki taraf da bundan olumlu şekilde faydalanmaktadır. Propaganda ise amaca giden yolda hedef olarak belirlediği kişi, grup ve ideolojiye doğrudan saldırır ve onları güçsüzleştirmeye çalışarak kendine taraftar toplamaya çalışır (Ayhan, 2007, s. 39).

Melissen'e göre, Birinci Dünya Savaşı sonrası ortaya çıkan yeni diplomasi anlayışı, propaganda gibi tek taraflı değildir (Melissen, 2005, s. 18). Bu dönemde "yabancı izleyicileri de angaje edecek" iki taraflı bir iletişim stratejisi gündeme gelmiştir (Yanardağoğlu, 2014, s. 116). Pamment de benzer olarak kamu diplo- 
masisini propagandadan farklı olarak "diyalojik, geniş kapsamlı ve iş birliği yanlısı" olarak nitelendirmektedir (Pamment, 2013, s. 3). Kamu diplomasisinde propagandada olduğu gibi tek yönlü bir iletişim değil, çift taraflı bir iletişim ve etkileşim görülmektedir. Kamuoyunun dinlenmesi ve önceliklerinin belirlenmesi kamu diplomasisinin birincil hedefidir.

\section{Hindistan'ın Yumuşak Güç Politikası ve Kaynakları}

Hindistan hem tarihsel süreçte eski uygarlıklar hem de modern dönemin Batılı sömürge imparatorlukları için bir cazibe merkezi olmuştur. Hindistan'ı işgal eden modern dönemin Batılı sömürge imparatorlukları zenginleşip dünyanın diğer ulusları üzerinde iktidar sahibi olurken, Hindistan gittikçe fakirleşmiştir (Yıldırım, 2013, s. 194). Ingiltere'den bağımsızlığını 15 Ağustos 1947'de kazanan Hindistan, yabancı yatırımcılara uygun hukuki ve ekonomik bir zemin hazırlamak için geliştirdiği politikaları sayesinde güçlü bir ekonomiye sahip olmaya başlamıştır (Önal, 2019, s. 333). Günümüzde Pakistan, Çin ve Afganistan'a olan coğrafi yakınlığı sebebiyle önemli bir stratejik konuma sahip olan Hindistan, Soğuk Savaş döneminde bağlantısızlar hareketinin önemli bir figürü olarak Doğu Bloğuna yakın bir duruş sergilemiştir. Fakat, SSCB'nin dağılması sonucunda Orta Asya'da ortaya çıkan siyasi istikrarsızlıklar, Hindistan'ın güvenlik endişelerini artırmıştır (Purtaş, 2006, s. 57). Hindistan bu süreç sonucunda dış politikada; toprak bütünlüğü ve egemenliğe karşılıklı saygı, saldırmazlık, eşitlik ve karşılıklı çıkar politikalarını ön plana çıkarmaya başlamıştır (Önal, 2019, s. 333).

Bağımsızlığından itibaren "kültürel ilişkiler" yoluyla tanınırlığını arttırmayı amaçlayan Hindistan, 2006 yılında Dışişleri Bakanlığı'na bağlı olarak kurduğu Kamu Diplomasisi Bölümü'nün yanı sıra Hindistan Kültürel İlişkiler Konseyi (ICCR), Turizm Bakanlığı ve diğer bakanlıklar ile sistemli bir şekilde hedeflerine ulaşmak için yumuşak güç kaynaklarını kullanma politikalarına hız vermiştir (Önal, 2019, s. 335). Hindistan'ın yumuşak gücünü oluşturan birçok unsur olsa da ülkenin küresel statüsünü güçlendirmesine ve marka bilinirliğini artırmasına yardımcı olan gerçek yumuşak güç kaynaklarının hangileri olduğunu belirlemek oldukça zordur. Tanrıların ülkesi olarak tanımlanan Hindistan'da Hinduizm, Budizm, Jainizm ve Sihizm başta olmak üzere Hristiyanlık, Yahudilik ve İslam gibi birçok dini inanç bulunmaktadır (Mohapatra, 1990, s. 119-138). Hindistan'ın uzun yıllar İngiliz sömürgesinde kalmasından dolayı ülkedeki İngiliz dilinin kullanım yaygınlığı ve İngilizce eğitim veren köklü eğitim kurumlarının varlığı, düşük öğrenim harçları ve düşük yaşam maliyeti, uluslararası öğrencileri ülkeye çeken önemli yumuşak güç unsurlarıdır. Hindistan'ın her geçen gün büyüyen sağlık sektörü, artan yabancı yatırımcılarıyla büyüyen çok uluslu şirketleri, Hint mutfağı, yogası ve antik bir sağlık sistemi olan Ayurvedası, ülkenin diğer yumuşak güç unsurları olarak sıralanabilir. Ayrıca, Hindistan 2004 yılında denizaşıı ülkelerde yaşayan ve çalışan geniş çaplı Hint diasporası ile diyalog halinde olmak amacıyla Yurtdışı İşleri Bakanlığı'nı kurmuş ve kamu diplomasisi çalışmalarını denizaşırı ülkelerde yaşayan Hint diasporası ile birlikte yürütmeye başlamıştır (Önal, 2019, s. 334). Bununla birlikte, Hindistan hükümeti; Avrupa, Amerika ve Asya'daki 
ülkelerde kurduğu kültür merkezlerindeki Hintçe dil kursları, film festivalleri, kitap fuarları ve sanat sergileri ile Hindistan'ın çok kültürlü toplum imajını tanıtmaya başlamıştır (Sertel, 2015, s. 299-300).

Hindistan Dışişleri Bakanlığı, 2006 Davos zirvesinde Kaşmir şallarını, Hint müziklerini ve Bollywood sinemasını tanıtırken, 2007 yılında "Inanılmaz Hindistan" (Incredible India) kampanyasıyla Hindistan'ın marka bilinirliğini artırmayı amaçlamıştır. Bununla birlikte, sivil toplum örgütleriyle işbirliği içerisinde olan Hindistan'ın, Birleşmiş Milletler içerisinde yer alan ülkelerin desteği ile 21 Haziran'ı Uluslararası Yoga Günü ilan etmesi, Uzakdoğu hükümet gezilerinde Budizm inanç ortaklıklarını kullanması, Pakistan'la ticaret ve seyahat bağları konusunda önemli adımlar atması ve Afgan öğrencilerine burs sağlaması, Hindistan'ın marka bilinirliğini artırmak için gerçekleştirdiği önemli çalışmalar arasında gösterilebilir (Önal, 2019, s. 335).

\section{Bir Kamu Diplomasisi Aracı Olarak Bollywood}

Algıları şekillendiren ve bellekleri arzulanan politik hedeflere ulaştırabilen sinema, içinde bulunduğumuz küreselleşme sürecinde; devletler, hükümetler, kişiler ya da grupların kendi düşüncelerini, fikirlerini, inançlarını, sosyal, siyasal ve kültürel değerlerini öteki toplumlara ulaştırabilmesi ve onları etkileyebilmesi nedeniyle önemli bir yumuşak güç kaynağıdır (Pınar, 2017, s. 263). Yumuşak güç unsurlarını dış kamuoyuna aktarma potansiyeli bulunan Hindistan'ın etkili araçlarından birisi de Bollywood sinemasıdır. Günümüzde, Hindistan film endüstrisi olan Bollywood, sinema sektöründe önemli bir konumda olup tüm dünyaya ulaşabilmekte, hedef kitlelerin algılarını ve düşünce yapılarını etkileyebilmektedir (Şentürk ve Kozluklu, 2020, s. 73).

Tarihsel olarak kolonyalizm ve postkolonyalizm sürecinde doğan Bollywood, geçmişten günümüze büyük ilerlemeler katetmiştir. Hindistan, sinema ile ilk olarak 1898 yılında Hiralal Sen tarafından yönetilen The Flower of Persia adlı kısa film ile tanışmıştır. Matbaacı ve düşünür Dhundiraj Govind Phalke, 1910'da İsa'nın Hayatı adlı kısa Fransız filmini izlerken Krishna gibi Hint dinî figürleri üzerine de filmler yapılabileceğini düşünür. Phalke tarafından yönetilen ilk uzun metrajı Hint filmi "Raja Harishchandra", 1913'te Hindistan'da gösterime girdikten sonra gişede büyük bir başarı elde eder. Bu nedenle, 2013 ylı Bollywood'un 100. yılı olarak kutlanmıştır (Saran, 2012, s. 41). Hindistan'daki ilk sesli film olan Alam Ara (Dünya Güzeli) ise 1930 yılında çekilmiştir. Bu tarihten sonra Hindistan sineması, ses teknolojisindeki gelişmeler ve şehirlerde artan film stüdyoları ile 20.yüzyılda gelişmeye devam ederek popüler bir eğlence aracı haline gelmiştir (İri, 2014, s. 24).

Hindistan'da, 1949 yılında Filmler Departmanı ve 1960 yılında Maliye Bakanlığı'na bağlı film yapımcılarına finansal destek sağlayan Film Finans Kurumu kurulmuştur (Gülhanım, 2009, s. 2). Bugün üretilen film sayısı bakımından dünyanın en büyük film endüstrilerinden biri olan Hint film endüstrisinin ana merkezleri 
ise Hyderabad, Bangalore, Mumbai, Chennai ve Kalkata'dır. Mumbai, Hintçe çekilen ve Bollywood adı verilen popüler Hint sinemasının doğduğu yerdir. Hindistan'da, Bollywood'un yanı sıra bölgesel dillerde filmler yapan bölgesel sinema endüstrileri de bulunmaktadır. Günümüzde, Hindistan film endüstrisinin ekonomik büyüklüğü yaklaşık 1,83 milyar dolardır. Bollywood film endüstrisi günümüzde artan film stüdyoları, bütçe, uluslararası ortak yapımlar ve dijital sinema kompleksleri ile küresel bir boyut kazanmıştır. Hint film endüstrisinin küreselleşmeye başlaması; ülke turizminin gelişmesi ve yeni iş sahalarının ortaya çıkmasının yanı sıra teknolojik ve kültürel birçok kazanımın ortaya çıkması açısından önemli avantajlar sağlamıştır (íri, 2014, s. 30).

\section{Bollywood Sineması ve Pakistanlı Temsili}

Ingiltere'nin 1947 ylında Hint alt kıtasındaki askeri mevcudiyetine son vermesi ile bölgede Pakistan ve Hindistan olmak üzere iki ülke kurulmuştur (Muqarrab, 2011, s. 5). Bu ülkelerin kuruluş sürecinde meydana gelen çatışmalardan dolayı bir milyondan fazla insan hayatını kaybetmiştir (Özev, 2012, s. 153). Bu tarihten sonra, Hindistan ile Pakistan arasında 1965 ve 1971 yıllarında, Doğu Pakistan ve Keşmir bölgeleri için iki savaş daha yaşanmıştır (Sehgal, 2011, s. 188195). Hindistan ve Pakistan arasında gerçekleşen bu çatışmalar, iki ülkenin ekonomik ve politik yapısı üzerinde olumsuz etkiler bırakmıştır (Bhat, 2018, s. 43). İki ülke arasındaki bu tarihsel gerginlik sinemaya da yansımıştır. Örneğin; Dishoom (2016), Raanjhanaa (2013) ve Neerja (2016) gibi Hindistan filmleri, Ghar Kab Aao Gay (2000) ve Saya e Khuda e Zuljalal (2016) gibi Pakistan filmleri, iki ülke arasındaki gerilimleri konu alan filmlerden bazılarıdır.

Geçmişten günümüze insanlar, var olan toplumsal iktidarı devam ettirmek için kendisini politik görüş, cinsiyet, inanç ve değerler bağlamında tanımlarken kendisi gibi olmayanı daima olumsuz bir referans olarak kullanmıştır (Özensel, 2020, s. 370). Sinema, bir propaganda aracı olarak kullanıldığı takdirde toplumda var olan ötekileştirici söylemsel pratikleri yeniden üreten ve kuvvetlendiren bir aygıt olarak değerlendirilebilir (Merskin, 2004, s. 159). Ülke imajının ve bilinirliğinin artması için Hindistan'a dair birçok yumuşak güç unsurunun tanıtılı̆ğı ve pazarlandığı Bollywood sineması da bu süreçte Pakistanlıları bir "öteki" olarak temsil edebilmektedir (Kumar 2013, s. 463). Atif ve Shaliq (2019), Mushtaq, Baig ve Iftikhar (2016) ve Hafeez (2017)'ın çalışmaları da Bollywood sinemasının, Pakistanlıları olumsuz bir şekilde temsil ettiğini göstermiştir. Sial, Arafat ve Zafar'ın çalışması, Bollywood sinemasındaki Agent Vinod, Ek Tha Tiger ve The Attacks of 26/11 filmlerinin, Pakistanlıları terörist ve kötü adam olarak yansıttığını göstermiştir (2019, s. 135). Ayrıca, Rasul'un $(2015$, s. 3) çalışmasında, Pakistanlıların Border (1997), LOC: Kargil (2003) ve Lakshya (2004) gibi Bollywood filmlerinde düşman olarak tasvir edildiği görülmüştür. Yayınlandığı dönemde çok fazla izlenen Fanaa (2006), Kurbaan (2009) ve Gadar: Ek Prem Katha (2001) gibi filmler de doğrudan Pakistan karşıtı olarak üretilen ve Pakistanlıların terörist, düşman ve tehlikeli olarak temsil edildiği diğer filmlerdir (Khatun, 2016, s. 48). Bollywood sinemasında 
görünürde olumlu fakat derin bir okuma sonucunda propaganda sinemasına yakın bir yaklaşım ile üretilen ve Pakistanlıların olumsuz olarak temsil edildiği filmler de bulunmaktadır. Bu araştırma, 1947'den sonra uluslararası arenada yeni bir kimlik inşa süreci içerisine giren Hindistan'ın, Bollywood filmlerindeki Pakistanlı temsilleri üzerinden nasıl kendini siyasal ve kültürel bağlamda öne çıkardığını Bajrangi Bhaijaan filmi üzerinden incelemektedir.

\section{Araştırma Yöntemi}

Saussure ve Peirce tarafından temelleri atılan göstergebilim, kitle iletişim sürecinde aktarılan dilsel veya görsel gösterge dizgelerini çözümlemek için kullanılan bir yöntemdir (Bignell, 2002, s. 5-6). Göstergebilimin amacı sonsuz çeşitlilikteki göstergeleri ortaya çıkararak, yapıların görünen yüzünün altında yer alan gizil anlamları ortaya çıkarmak ve bu vesileyle "yapıları" anlamaktır (Sancar, 2018, s. 26). Göstergebilimi sinemaya uygulamış olan Christian Metz, göstergebilimsel analizin, sinema filmlerindeki gizil anlamları ortaya çıkarmak için kullanılabileceğini ifade etmiştir (Andrew, 2010, s. 324). Görselliği ve ișitselliği bir arada kullandığı için insanlar üzerinde son derece önemli etkiler bırakabilen sinema, sunduğu yan ve düz anlamlar ile belli ideolojik mesajlar aktarabilmektedir (Stojanova, 2017, s. 134-135).

Sinemada anlamın aktarımasını sağlayan göstergeler bulunmaktadır. Barthes, bu göstergeleri düz anlam ve yan anlam olarak ikiye ayırmaktadır. Anlamlandırma sürecinde yer alan düz anlamıyla gösterenin gönderme yaptığı kavram ifade edilmektedir. Yan anlam ise bir anlam üretme sürecine işaret etmektedir. Yani yan anlamlar, düz anlamın dışında olan ikinci anlamları ifade etmektedir. Düz anlam, nesnenin zihinde yarattığı bir yansıma olarak değerlendirilirken, yan anlam göstergenin izleyicilerin duyguları ve kültürel değerleriyle olan ilişkisine odaklanmaktadır (Batı, 2005, s. 175). Bu çalışma, Bajrangi Bhaijaan filminin Hindistan'ın, ülkesine dair birçok yumuşak güç unsurunu tanıtırken, Pakistanlılara dair nasıl yan ve düz anlamlar oluşturduğunu göstergebilim ile incelemektedir. Bu incelemenin, literatürde belirtilen kavramsal çerçeveye dair sınırlı bir saha sunmakla birlikte, Türkiye'de Bollywood sinemasına dair bu bağlamda gerçekleşecek olan çalışmalar için bir referans niteliği taşıyabileceği umulmaktadır.

\section{Göstergebilimsel Açıdan ‘Bajrangi Bhaijaan' Filminin Çözümlemesi}

Kabir Khan'ın yönetmenliğini üstlendiği Bajrangi Bhaijaan filmi 2015 yılında vizyona girmiştir. Film'in başrollerini, Bollywood filmlerinin en bilinen isimlerinden Salman Khan, Kareena Kapoor ve Harshaali Malhotra paylaşmıştır. Film, doğduğundan beri konuşamayan 5 yaşındaki Pakistanlı küçük Shahida diğer adı ile Munni'nin (Harshaali Malhotra) annesi ile birlikte tedavi için Hindistan'a gitmesi ile başlar. Munni, tedaviden sonra annesi ile Hindistan'dan Pakistan'a tren ile dönmektedir. Munni, Hindistan sınırında duran trenden çukura düşen bir kuzuya yardım etmek için iner ve hareket eden trene yetişemez. Munni'nin annesi, Pakistan sınırlarına girdikten sonra uyanır ve kızının trende olmadığını fark eder. Anne, 
küçük kızını aramak için geri dönmek istese de Pakistan ve Hindistan arasındaki Keşmir sorunundan dolayı Hindistan sınıından tekrar giriş yapamaz ve Pakistan'a geri dönmek zorunda kalır. Munni ise Hindistan'da bir dini festival alanında Bajrangi Bhaijaan'ın müridi olan Pavan (Salman Khan) ile karşılaşır. Pavan, konuşamayan bu küçük kızın kaybolduğunu anlar ve ona yardım etmeye çalışır. Munni'yi ailesine ulaştırmak isteyen Pavan, konuşamayan Munni'nin et yemesi, mescide gitmesi ve Hindistan-Pakistan maçında gol atan Pakistan takımına sevinmesinden dolayı onun Pakistanlı bir Müslüman olduğunu anlar. Pavan, küçük Munni'yi ailesine götürmek istese de Hindistan ve Pakistan arasındaki politik gerginliklerden dolayı sınır kapılarından geçiş izni alamaz. Pavan, Munni ile birlikte Pakistan'a yasadışı bir şekilde giriş yaparak küçük kızı ailesine ulaştırmaya çalışır.

Christian Metz, göstergebilimsel analiz ile bir filmin her bir sahnesi ve bu sahneler arasındaki anlam ilişkileri içinden genelleştirme yapılabilecek bilimsel verilerin elde edebileceğini belirtmektedir (Metz, 2012, s. 131-132). Bajrangi Bhaijaan filminin incelendiği bu çalışmada, 8 sahne üzerinden filmin tamamına dair genelleştirme yapılabilecek veriler elde edilmiştir. Bu veriler, literatürde açıklanan kavramsal çerçeve ile ilişkilendirilerek, analiz edilmiştir.

Tablo 1 Göstergelerin Çözümlenmesi



Görsel 1

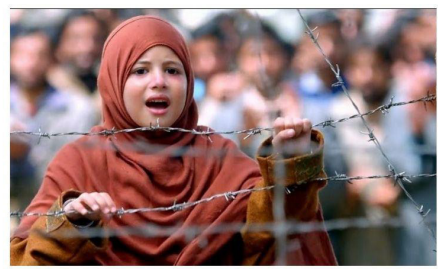

Görsel 3

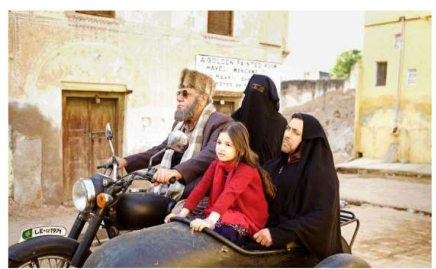

Görsel 2

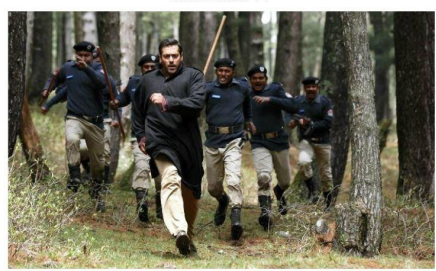

Görsel 4 


\begin{tabular}{|c|c|c|}
\hline Gösterge & Gösteren & Gösterilen \\
\hline $\begin{array}{l}\text { Görsel 1; } \\
\text { Insanlar, Doğa, } \\
\text { Nesne }\end{array}$ & $\begin{array}{|lr|}\text { Toplantı, } & \text { Tartışma, } \\
\text { Nargile, Cübbe, Şalvar, } \\
\text { Takke }\end{array}$ & $\begin{array}{l}\text { Geleneksel Kıyafetler Giyen } \\
\text { Muhafazakar Müslümanlar ve } \\
\text { Kırsal Yaşam }\end{array}$ \\
\hline $\begin{array}{l}\text { Görsel 2; İnsanlar } \\
\text { ve Nesne }\end{array}$ & Yolculuk & $\begin{array}{l}\text { Nikap Giyen Muhafazakar } \\
\text { Müslüman Kadın, Sakallı } \\
\text { ve Takkeli Muhafazakar } \\
\text { Müslüman Erkek }\end{array}$ \\
\hline $\begin{array}{l}\text { Görsel 3; İnsanlar } \\
\text { ve Nesne }\end{array}$ & Küçük Kız ve Demir Teller & \begin{tabular}{|lrr} 
Pakistan'da & Küçük & Kız \\
Çocuklarının & Küçük & Yaşta \\
Kapanmak Zorunda Kalması
\end{tabular} \\
\hline $\begin{array}{l}\text { Görsel 4; İnsanlar } \\
\text { ve Nesne }\end{array}$ & Asker, Jop ve Koşma & $\begin{array}{l}\text { Şiddet Uygulayan Öfkeli } \\
\text { Pakistanlı Müslüman Askerler } \\
\text { ve Yardımsever Hindistanlı } \\
\text { Adam }\end{array}$ \\
\hline
\end{tabular}

Birinci ve İkinci Dünya Savaşları'nın ardından özgürlüklerini kazanan devletler, sınıllarını etnik ya da dini kimlikler üzerinden katı çizgilerle tanımlayan Avrupa ulus-devletler sistemini örnek almaya başlamıştır (Arent, 2016, s.19). Pakistan, 14 Ağustos 1947 tarihinde Hindistan'dan bağımsızlığını kazanmıştır. Fakat, Pakistanın bağımsızlığından sonra iki ülke birbirleri için sürekli ve değişmez düşmanlar olarak kalmaya devam etmiştir. Bu tarihten sonra Bollywod sinemasında Pakistanlılar, olumsuz stereotipler ile temsil edilmeye başlanmıştır. Bajrangi Bhaijaan filminin ilk sahnesi (Görsel 1) Pakistan'ın Sultanpur köyünde geçmektedir. Bu sahnede erkekler Munni'nin Hindistan'a tedavi için nasıl gidebileceğini konuşmaktadır. Bu sahnede, erkeklerden biraz daha uzak bir mesafede oturan kadınlar ise çekingen bir şekilde sohbete dahil olmaktadır. Bu sohbette Hindistan ve Pakistan arasındaki gerilimin, bu yolculuk için bir engel teşkil edebileceği hakkında konuşulmaktadır. Sohbet şöyle gerçekleşmektedir:

Dede:Sana kaç zamandır Şahida'yı (Munni) Delhi'deki Hz. Nizam'ın Dergahına götür dedim. Orada dilsizler bile konuşmaya başlıyor. Ben beş yaşıma kadar hiç konuşamıyormuşum, beni de oraya götürmüşler.

Baba:Ama artık Delhi Hindistan toprağında?

Dede:Ne olmuş yani Amerika'da değil ya?

Baba:Amerika'da olsa daha kolay olurdu baba. Eskiden biz tek ülke tek millettik. Ben beş yıl Pakistan ordusuna hizmet ettim. Şimdi 
Hintliler bana vize vermez.

Bu sahnede, Pakistanlıların kültürel ve tarihsel bir zenginliğe sahip olan Hindistan'a duydukları özleme ve bu özleme neden olan iki ülke arasındaki gerginliğe vurgu yapılmaktadır. Genel olarak, Görsel 1'in alındığı sahnede, Pakistanlılar çobanlık yapan, kırsal bölgelerde yaşayan, geleneksel tedavi yöntemlerine inanan kişiler olarak temsil edilmektedir. Bu sahnede, kadınların nikaplı ve ev hanımı olduğu, erkeklerin de geleneksel kıyafetler giydiği ve sakallı olduğu görülmektedir. Bununla birlikte, Pakistan'ın erkek otoritesine dayanan bir toplumsal yapı ile temsil edildiği görülmektedir.

Oryantalizm okumalarında "fantazmatik" ve "erişilmez" bir figür olarak "Doğulu ve Müslüman Kadın”, örtülü ve peçeli imajlarla temsil edilmektedir (Özendeş, 1999, s. 160-166). Görsel 2'de de Müslüman kadınların siyah nikap giydikleri görülmektedir. Bu sahnede Pavan ve gazeteci Chand, Pakistan'daki güvenlik güçlerine yakalanmamak için kadın kıyafetleri giymekte ve imam onları kendi eşleri olarak diğer insanlara tanıtmaktadır. Ayrıca, bu sahnede yine Pakistanlı Müslüman erkeklerin sakallı, takkeli ve çok eşli olarak temsil edildiği görülmektedir. Görsel 3'te de benzer olarak 5 yaşındaki Munni'nin Hindistan'da geçen sahnelerde türban takmadığı görülmektedir. Munni Hindistan'da geçen sahnelerde tişört veya sari giymektedir. Fakat Munni'nin Pakistan'da geçen sahnelerin çoğunda türban taktığı ve geleneksel Pakistan kıyafetleri giydiği görülmektedir. Pakistan'ın kıyafetler üzerinden muhafazakar ve kapalı bir toplum olarak tasvir edildiği bu sahneler, Hindistan'ı "modern", "özgür" ve "eşitlikçi" olarak konumlandırmaktadır.

Oryantalist bakış açısı Müslümanları siyah elbiseli, uzun sakallı ve silahIı olarak tasvir ederken, İslamı da barbar ve despotik olarak tanımlar (Gürler ve Özdemir, 2014, s. 147). Görsel 4'teki Pakistanlı Müslüman asker imgesi, hem oryantalist bakış açısının hem de Hindistan-Pakistan arasındaki tarihsel olarak süregelen gerilimlerin bir yansıması olarak görülebilir. Bajrangi Bhaijaan filminin Hindistan'da geçen sahnelerinde, Hintli askerler Pavan ve Munni'nin Pakistan'a geçmesini sağlayan yardımsever ve kuralcı askerler olarak temsil edilmektedir. Fakat Görsel 4'ün alındığı sahnede, Pakistanlı askerlerin Pavan'a karşı sinirli ve şiddet yanlısı bir tavır takındıkları görülmektedir. Bu sahnede Pakistanlı askerler, Munni'yi ailesine ulaştırmaya çalışan Pavan'ın bir casus olduğunu düşünmektedir. Bundan dolayı, Pavan sahne boyunca Pakistanlı askerler tarafından şiddete maruz kalmaktadır. 
Tablo 2: Göstergelerin Çözümlenmesi

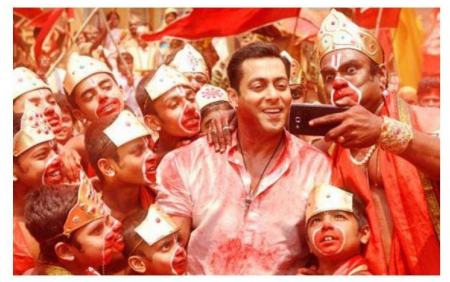

Görsel 5

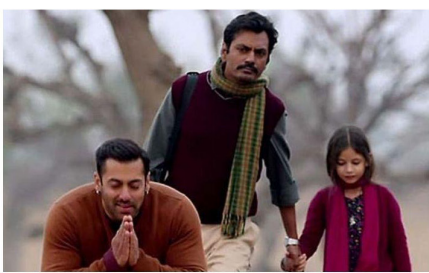

Görsel 7

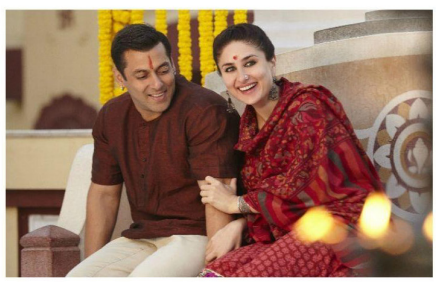

Görsel 6

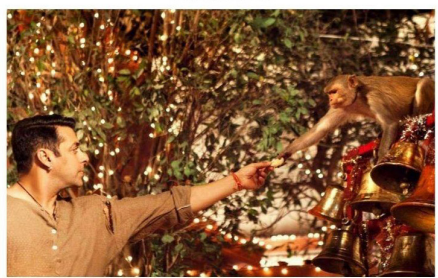

Görsel 8

\begin{tabular}{|l|l|l|}
\hline Gösterge & Gösteren & Gösterilen \\
\hline $\begin{array}{l}\text { Görsel 5; Insanlar, } \\
\text { Tapınak ve Nesneler }\end{array}$ & $\begin{array}{l}\text { Fotoğraf Çekme, Dini } \\
\text { Kostümler, Makyaj, } \\
\text { Telefon, Selfie }\end{array}$ & $\begin{array}{l}\text { Hindistan Yerel Dansları ve } \\
\text { Takip Ettikleri Küresel Trendler } \\
\text { ile Hem Modern Hem } \\
\text { Geleneksel Olanı Bir Arada } \\
\text { Barındııı. }\end{array}$ \\
\hline $\begin{array}{l}\text { Görsel 6; Insanlar ve } \\
\text { Nesne }\end{array}$ & Konuşan Eşler & $\begin{array}{l}\text { Hindistan Geleneksel Kıyafeti } \\
\text { Olan Sarisi, Bindu Sembolü } \\
\text { ve Dini Süsleri ile Nikap Giyen } \\
\text { Pakistanlı Kadınlardan Farklı } \\
\text { Olarak Hem Modern Hem } \\
\text { Geleneksel Olanı Bir Arada } \\
\text { Barındırır. }\end{array}$ \\
\hline $\begin{array}{l}\text { Görsel 7; Insanlar, } \\
\text { Ağaç, hayvan }\end{array}$ & $\begin{array}{l}\text { Dua Eden Adam ve } \\
\text { Küçük Kız }\end{array}$ & $\begin{array}{l}\text { Hindular Doğa'ya } \\
\text { Hayvanlara Saygı Duyar. }\end{array}$ \\
\hline $\begin{array}{l}\text { Görsel 8; İnan ve } \\
\text { Hayvan }\end{array}$ & $\begin{array}{l}\text { Maymun'a yiyecek } \\
\text { veren bir insan. }\end{array}$ & $\begin{array}{l}\text { Hindular Hem Doğa'ya ve } \\
\text { Hayvanlara Saygı Duyar Hem } \\
\text { de Paylaşmayı Severler. }\end{array}$ \\
\hline
\end{tabular}

Hindistan, Bollywood üzerinden eğitim sistemini, dinsel yapısını, mutfağını, sağılık sektörünü, danslarını, kıyafetlerini ve müziğini dış ülkelere tanıtmaktadır. Görsel 5'te kendini "Tanrıların Ülkesi" olarak tanımlayan Hindistan'ın, film üzerinden Hinduizm'i tanıttığı görülmektedir. Ayrıca, film sahnesi yerel Hint dansla- 
rını, şarkılarını ve elbiselerini "selfie" gibi küresel akımlar ile birlikte göstererek, Hindistan'ın hem geleneksel hem de modern olanı bir arada barındıran bir ülke olduğu mesajını vermektedir. Görsel 6'da da benzer olarak Hindistan'ın küresel olmaya başlayan Sari elbiseleri ve Hindu geleneğinin önemli bir sembolü olan 'bindi' işareti ön plana çıkarılmıştır. Bununla birlikte, filmdeki bu sahne erkek otoritesine dayanan Pakistan aile yapısının karşısına modern ve geleneksel olanı bir arada barındıran, eşitlikçi bir Hintli aile imgesi koymaktadır.

Hindistan'ın mutfak kültürünü etkileyen önemli öğelerden biri olan Hinduizm, "Ahimsa" adı verilen "Şiddetsizlik Yasası" ile vejeteryanlığı ahlaklı bir yaşam biçimi olarak tanımlamaktadır (Chapple, 1993, s. 3). Bu bağlamda, Hinduizm dinine mensup insanlar, doğa'ya ve inek gibi hayvanlara kutsal olduklarını düşündükleri için büyük bir saygı duymaktadırlar. Filmin birçok sahnesinde olduğu gibi Görsel 7'de de Pavan doğa'ya ve kutsal olarak kabul edilen ineğe saygısını sunmaktadır. Görsel 8 de benzer olarak "ahlaklı bir yaşam biçimi" olarak vejeteryanlığı benimseyen, paylaşımcı ve doğa'ya saygılı bir Hindu tasviri yapmaktadır. Fakat, filmde et yemek isteyen 5 yaşındaki Munni, Hintli insanlar tarafından garipsenirken, bir çiftçi olarak tasvir edilen Pakistanlı aile "Şiddetsizlik Yasasının" tam karşısına konulmaktadır.

Tablo 3: Karşıtlıklar

\begin{tabular}{|l|l|}
\hline Hindistan & Pakistan \\
\hline Heterojen Toplum & Homojen Toplum \\
\hline Modern ve Geleneksel & Geleneksel \\
\hline Sakin ve Kuralcı & Öfkeli ve Kuralcı \\
\hline Eşitlikçi & Ataerkil \\
\hline Güvenilir & Güvenilmez \\
\hline Kent Yaşamı & Kırsal Yaşam \\
\hline Liberal/Tutucu & Tutucu \\
\hline
\end{tabular}

\section{Sonuç}

Ağ toplumunun etkisi ile "Kamuoyu Yüzyılı" olarak tanımlanmaya başlanan 21. yüzyıl, devletlerin dış kamuoyu ile ortak paydalar bulma ve köklü ilişkiler inşa etme sürecine girdiği bir dönemi tanımlamaktadır. Bu dönemde sert güç yerini yumuşak güç unsurlarına bırakmış ve kamu diplomasisi, stratejik bir faaliyet alanı olarak gündemde daha fazla yer almaya başlamıştır. Günümüzde, yumuşak güç unsurlarını dış kamuoyuna aktarma potansiyeli bulunan Hindistan'ın etkili araçlarından birisi de Bollywood sinemasıdır. Hindistan, Bollywood üzerinden geleneklerini, danslarını, giysilerini, müziklerini, mimari üsluplarını ve inançlarını dış kamuoyuna pazarlamaktadır. Bu araştırma, Bajrangi Bhaijaan filminin göstergebilimsel analizi ile Hindistan'ın, ülkesine dair birçok yumuşak güç unsurunu tanıtırken, $\mathrm{Pa}$ - 
kistanılıarı nasıl temsil ettiğini analiz etmiştir. Filmde, Hindistan'ın kültürü, sanatı ve dinsel öğeleri olumlu imgeler ile tanıtılırken, Pakistanlılar ve bununla birlikte Müslümanlar "ataerkil", "öfkeli" ve "tutucu" gibi portreler ile temsil edilmiştir.

Pakistanlılara dair bu olumsuz temsilin ortaya çıkmasında, Hindistan hükümetinin Bollywood üzerindeki etkisi rol oynayabilir. Anderson (2006), Herman ve Chomsky (2002) ve Schiller (2011) çalışmalarında, devletlerin medya pazarındaki etkisine dair bulgular ortaya koymuştur. Hindistan hükümeti de eğlence vergisini azaltarak ve film üreticilerine düşük faizli krediler sunarak, bu film endüstrisinin büyümesine yardımcı olmuştur. Hindistan hükümeti, bu finansal desteğin yanı sıra sosyal, politik, ekonomik ve ideolojik baskılar ile filmlerin üretim süreçlerini etkileyebilmektedir. Nitekim, Rasul'un çalışması da (2015) Bollywood'un Hindistan hükümetinin bölgedeki siyasi gündemi ile paralel olarak filmler ürettiğini ortaya koymuştur. Bollywood filmlerinde işlenen temaların, dönemin politik anlayıŞı ile paralel olarak değiştiği görülmektedir. Örnek olarak, LOC: Kargil (2003) ve Lakshya (2004) gibi filmler, Hindistan hükümetinin bu dönemdeki dış politikası ile uyumlu olarak vatanseverlik ve milliyetçilik temalarını işlemiştir. Hindistan ve Pakistan arasındaki gerilimlerin 2003'ten sonra azalması ile de Veer-Zaara (2004) ve Main Hoon Na (2004) gibi iki ülke arasındaki uyumu ve dostluğu pekiştiren filmler üretilmeye başlanmıştır (Rasul, 2015, s. 77-78). Bajrangi Bhaijaan filminin vizyona girdiği 2015 yılında, iki ülke arasında büyük gerilimler yaşanmamıştır. Bajrangi Bhaijaan da görünürde iki ülke arasındaki uyumu ve dostluğu pekiştiren bir film olarak görülebilmektedir. Fakat, derin bir okuma sonucunda filmin, Hindistan'ın birçok yumuşak güç unsurunu tanıtırken, Pakistanlıları olumsuz bir şekilde temsil ettiği görülmüştür.

\section{Kaynakça}

Arent, H. (2016). Totalitarizmin Kaynakları-2 Emperyalizm. (Çev. B. S. Şener) 5. Baskı. İstanbul: Iletişim Yayınları.

Anderson, R. (2006) A century of media: a century of war. New York: Peter Lang. Ayhan, A. (2007). Propaganda Nedir? İstanbul: Literatürk Yayınları.

Andrew, J. D., (2010). Büyük Sinema Kuramları (Çev. Zahit Atam), İstanbul: Doruk Yayımcilık.

Atif, K., Shaliq, Z. (2019). Discourse on Terrorism: Image of Pakistan in Bollywood film, Phantom (1), 164-180.

Batı, U. (2005). Bir Anlam Yaratma Süreci ve İdeolojik Yapı Olarak Reklamların Göstergebilim Bir Bakış Açısıyla Çözümlenmesi. Cumhuriyet Üniversitesi Sosyal Bilimler Dergisi, 29, 175-190.

Bhat, M. A. (2018). The Strategic Cooperation among India, Pakistan, Iran and Central Asia and its implications upon the Regional Stability. The Journal of Iranian Studies, 2 (1), 41-60. 
Bignell, J. (2002), Media Semiotics: An Introduction. Manchester University Press, Manchester.

Cull, N. J. (2007). Public diplomacy: Lessons from past. California; Figueroa Press. Erişim: 21 Kasım 2019, https://kamudiplomasisi.org/pdf/kitaplar/PDPerspectivesLessons.pdf

Chapple, C.K. (1993). Nonviolence to Animals, Earth and Self in Asian Traditions. State University of New York Press: Albany, NY, USA.

Efegil, E. (2018). Türk Dış Politikası ve Kamu Diplomasisi, Kamu Diplomasisi Enstitüsü. Erişim: 10 Kasım 2019, http://www.kamudiplomasisi.org/makaleler/makaleler/94-tuerk-di-poltkasi-ve-kamu-dplomass

Karadağ, H. (2016). Uluslararası İlişkilerde Yeni Bir Boyut Kamu Diplomasisi. Ankara:Nobel Akademik Yayıncılık.

Gökırmak, M. (2012). Küreselleşen Dünyada Diplomasi: Kamu Diplomasisi, TASAM. Erişim: 21 Kasım 2019, http://www.kamudiplomasisi. org/ana-sayfa/44-makaleler/124-kuereselleen-duenyada-diplomasi-kamu-diplomasisi-.pdf

Gülhanım, G. (2009). Sinema Devlet Illişkisi: Dünyadan Örnekler ve Türkiye. T.C Kültür ve Turizm Bakanlığı, Araştırma ve Eğitim Genel Müdürlüğü, IV Dönem Uzmanlık Tezleri. Erişim:21Kasım 2019, http://aregem.kulturturizm.gov.tr/Eklenti/31141,gulhanimgulpdf.pdf?0

Hafeez, E. (2017). Depiction of Violent Crimes in Bollywood Cinema and its impact on Pakistani Society, Jhss, 8 (1), 21-32.

Herman, E. S., Chomsky, N. (2002) Manufacturing consent: the political economy of the mass media. New York: Pantheon.

İri, M. (2014). Bollywood Sineması: Hindistan'ın Hareketli Resim Sanayii Üzerine Notlar. Galatasaray Üniversitesi İletişim Dergisi, (18), 21-34.

Kalın, I. (2011). Türk Dış Politikası ve Kamu Diplomasisi, TASAM, Erişim: 21 Kasım 2019, https://www.kamudiplomasisi.org/makaleler/makaleler/100-tuerk-d-politikas-ve-kamu-diplomasisi

Khatun, N. (2016). Imagining Muslim Identity in Muslim Political Films. Journal of Arab \& Muslim Media Research, 9 (1), 41-60.

Kumar H. M., S. (2013), 'Constructing the nation's enemy: Hindutva, popular culture and the Muslim "other" in Bollywood cinema', Third World Quarterly, 34 (3), 458-469.

Köksoy, E. (2013). Halkla İlişkiler Bağlamında Kamu Diplomasisi Yönetimi, İstanbul Üniversitesi Sosyal Bilimler Enstitüsü, Yayımlanmamış Doktora Tezi, İstanbul.

Kocabıyık, H. (2019). Değişen Diplomasi Anlayışı, Kamu Diplomasisi ve Türkiye, Avrasya Etüdleri,163-196. Erişim 22 Kasım 2019 http://www.avrasyaetudleri. com/uploads/articles/55/7.pdf 
Leonard, M., Stead, C., and Smewing, C. (2002). Public Diplomacy. London: The Foreign Policy Center.

Manheim, J. (2001). Talking Pointsfor Meeting with Staff of Senate Foreign Relations Committee, R. Christopher, Public Diplomacy Comes of Age içinde, The Washington Quarterly, printemps, 2002.

Metz, C. (2012). Sinemada Anlam Üstüne Denemeler (Çev. Oğuz Adanır), İstanbul: Hayalperest Yayınevi.

Melissen, J. (2005). The New Public Diplomacy: Soft Power in International Relations. New York: Palgrave MacMillan.

Merskin, D. (2004). The Construction of Arabs as enemies: Post-September 11 Discourse of George Bush', Mass Communication and Society, 7(2), 157-175.

Muqarrab, A. (2011). Pakistan's Foreign Policy: Internal Challenges in New Millennium, Berkeley Journal of Social Sciences, 1(2), 1-11.

Mushtaq, S., Baig, F., Iftikhar, G. (2016). Exploring Transition in Indian Perspective about Kashmir Issue through its Mainstream Cinema, Journal of Pakistan Vision, 18(1), 172-189.

Mohapatra, A., R., (1990). Philosophy of Religion an Approach to World Religions. India:Sterling Pub.

Nye, J. (2003) Amerikan Gücünün Paradoksu. İstanbul: Literatür Yayınclık.

Nye, J. (2005). Yumuşak Güç. Ankara: Elips Kitap.

Nye, J. (2008). Public Diplomacy and Soft Power, The Annals of American. Academy of Political and Social Science, 616 (94), s. 101.

Önal, B. (2019). Hindistan'ın Yumuşak Güç Politikları ve Türkiye-Hindistan İlişkilerindeki Rolü. Uluslararası Sosyal Araştırmalar Dergisi. 12(63), 333-240.

Özkan, A. (2007). Siyasal İletişim Stratejileri. İstanbul: Tasam Yayınları.

Özendeş, E. (1999). Fotoğrafta Oryantalizm, İstanbul: YKY.

Özev, M. (2012). Küresel ve Bölgesel Güçlükler Karşısında Pakistan'ın Demokratikleşme Çabaları. Güvenlik Stratejileri Dergisi, 8 (16), 147-176.

Özensel, E. (2020). Farklııkların Birarada Yaşamasında Bir Sorun Alanı Olarak Ötekinin Ötekileştirilmesi, Selçuk Üniversitesi Edebiyat Fakültesi Dergisi, 0 (43), s. 369-378.

Pamment, J. (2013). New Public Diplomacy in the 21st Century, New York, Routledge.

Potter, E. (2002). Canada and the New Public Diplomacy, Discussion Papers in Diplomacy, Netherlands Institute of International Relations. Erişim: 23 Kasım 2019 https://www.peacepalacelibrary.nl/ebooks/files/Clingendael_20020700_ cli_paper_dip_issue81.pdf 
Pınar, L. (2017). Amerika Birleşik Devletleri'nin Yumuşak Gücü ve Hollywood, Insan ve Toplum Bilimleri Araştırmaları Dergisi, 6(1), 253- 274.

Purtaş, F. (2006). Avrasya'daki 'Büyük Oyun' Bağlamında Hindistan'ın Orta Asya Politikası, Orta Asya ve Kafkas Araştırmaları Dergisi, 1 (2), 56-84.

Rasul, A. (2015). Filtered Violence: Propaganda Model and Political Economy of the Indian Film Industry. Journal of Media Critiques, 1(2), 75-92.

Romarheim, A.G., (2005) Definitions of Strategic Political Communication. Norwegian Institute of International Affairs. Erişim: 23 Kasım 2019 https://www. files.ethz.ch/isn/27824/689.pdf

Sancar, G. A. (2012). Kamu Diplomasisi ve Uluslararası Halkla Illişkiler. İstanbul: Beta Yayınları.

Sancar, M. K. (2018). Göstergebilimsel Film Çözümlemelerinin Bergsoncu Eleştirisi. SineFilozofi Dergisi, 3(6), 24-38.

Saran, R. (2012). History of Indian Cinema. Diamond Pocket Books Ltd, New Delhi.

Sandıklı, A. (2014). Yumuşak Güç Savaşları, içinde, H. Çomak ve A. Gökalp Kutlu (ed.), Uluslararası Güvenlik Kongresi (183-205), 08-09 Ekim 2013, Kocaeli: Kocaeli Üniversitesi Yayınları.

Sertel, S. (2015). Demokrat Parti Döneminde Türkiye-Hindistan İlişkileri. International Journal of Social Science, 32 (3), 291-305.

Sehgal, R. (2011). Kashmir Conflict: Solutions and Demand for Self-determination, International Journal of Humanities and Social Science, 1 (6), 188-195.

Sial, N., Arafat, Y., Zafar, A. (2019). Pakistan in the Bollywood Movies: A Discourse Analysis. Journal of Indian Studies, 5(1), 125-136.

Stojanova, C. (2017). The Great War: Cinema, Propaganda, and The Emancipation of Film Language. Acta Universitatis Sapientiae, Film and Media Studies, (14), 131-156.

Schiller D (2011) The militarization of US communications. In: J. Wasko, G. Murdock, \& H. Sousa (Eds.). The handbook of political economy of communications (pp. 264-282). Oxford, UK: Wiley-Blackwell.

Şentürk K., E., Kozluklu, Ş. (2020). Yumuşak Güç Bağlamında Bollywood Filmlerinin Değerlendirilmesi: Inönü Üniversitesi İletişim Fakültesi Öğrencileri Üzerine Nitel Bir Araştırma. Uluslararası Halkbilimi Araştırmaları Dergisi, 3 (4), 73-109.

Taylor, P. (2009) "Public Diplomacy and Strategic Communications". N. Snow and P. Taylor, (Ed.), Routledge Handbook of Public Diplomacy içinde, New York: Routledge International Handbooks.

Temel, S. (2010). Amerikan Kamu Diplomasisinin 11 Eylül Sonrası Yönetim Anlayışı ve Sergilenen Faaliyetler Odağında İncelenmesi: Kamu Diplomasisindeki 
Değişimleri Anlamak, (Yüksek lisans tezi, Kara Harp Okulu, Ankara) Erişim: 23 Kasım 2019 https://www.academia.edu/6525951/Kamu_diplomasisi

Tiedeman A. (2004). U.S. Public Diplomacy in Middle East, Seminar on Geography, Foreign Policy and the World Order. Erişim: 23 Kasım 2019 http://media. leeds.ac.uk/papers/pmt/exhibits/2447/Anna_Tiedeman_Beers.pdf

Tuch, H. N. (1990). Communicating With the World: U.S. Public Diplomacy Overseas, New York: St.Martin's Press.

Yanardağoğlu, E. (2014). “Uluslararası İletişim ve Kamu Diplomasisi: BBC Dünya Servisi Haber Merkezi Örneği", İletişim, Kuram ve Araştırma Dergisi, (38); 116.

Yıldııım, L. (2013). Dış Politika'da Yumuşak Güç ve Seçili Örnek Hindistan. Ufuk Üniversitesi Kütüphanesi Sosyal Bilimler Dergisi. 2 (3), 184-209. 